УДК 687.016

DOI:

Наталія Фещенко, викладач кафедри дизайну

Хортицької національної навчально-реабілітаційної академії

\title{
ТВОРЧА ДІЯЛЬНІСТЬ ТА ЖИТТЕВИЙ ШЛЯХ ПРОВІДНИХ ДИЗАЙНЕРІВ ОДЯГУ СВІТОВОГО РІВНЯ, У КОНТЕКСТІ ПРОСКЦИЙНОГО САМОВДОСКОНАЛЕННЯ СТУДЕНТІВ ФАКУЛЬТЕТУ ДИЗАЙНУ
}

У статті розкривається сутність творчого становлення найбільш відомих дизайнерів, основні віхи їх життя, освіту і схильності, лідерські якості. Основна увага приділена їх мотивам як рушійної творчої сили, їх генезису і реалізації. Креативна складова особи подібна до іскри, що може запалити весь світ потенціалом нових ідей і нового бачення, але цій іскрі вчасно треба допомогти спалахнути, надихнути вірою в успіх $і$ в себе. Саме у ией ключовий момент близькі люди повинні підтримати художника i “підкинути хмизу” увогонь творчості.

Виокремлено проблеми молоді, які повинні пам'ятати, щзо в сучасному світі необхідним елементом будь-якої діяльності є комериійний успіх, який визначає подальщу долю будь-якого підприємства, в тому числі і модного будинку. Історія знає багато прикладів феноменально талановитих кутюр'є, наприклад Крістіан Лакруа, щуо створили безліч цікавих образів і ідей, але, тим не менш, потерпіли комериійний крах. 3 метою недопущення подібних сиенаріїв молоді фахівці повинні бути озброєні необхідним маркетинговим арсеналом впливу на публіку через ЗМІ, соиіальні мережі і блоги. Історична тенденція моди змішується у бік онлайн-сервісів, всіляких колаборацій і аутсорсингових послуг, тим більше це продиктовано нинішніми реаліями глобальних пандемій.

Ключові слова: мода; кутюр'є; самовдосконалення; кар'єра; освіта дизайнера; конструювання; моделювання; виробництво одягу.

Лim. 14.

Natalia Feshchenko, Lecturer of the Clothing Design Department Khortytsia National Rehabilitation Academy

\section{CREATIVE ACTIVITY AND LIFE PATH OF THE WORLD LEVEL FASHION LEADING DESIGNERS IN THE CONTEXT OF SELF PROJECTION AND SELF IMPROVEMENT OF STUDENTS IN THE FACULTY OF DESIGN}

Our goal - to trace the creative development of the most famous designers, the main milestones of their lives, education and aptitudes, leadership skills, help from family and friends. We are interested in their motives, as the driving force, their genesis and realization. The creative component of a person is like a spark that can ignite the whole world with the potential of new ideas and a new vision, but this spark must be helped to ignite in time, to inspire faith in success and in yourself. At this key moment close people must support the artist and "throw the bushes" into the fire of creativity.

But young talented people must remember that in today's world a necessary element of any activity is commercial success, which determines the future of any business, including a fashion house. History knows many examples of phenomenally talented couturiers, such as Christian Lacroix, who created many interesting fashions and ideas, but nevertheless suffered a commercial collapse. In order to prevent such scenarios, young professionals must be armed with the necessary marketing arsenal of influence on the public through the media, social networks and blogs. The historical trend of fashion is shifting towards online services, all kinds of collaborations and outsourcing services, especially as it is dictated by the current realities of global pandemics.

We will try to highlight the common path of becoming world-renowned masters of clothing, so that students have the opportunity to develop the same qualities and priorities in life and repeat the success story of these people. Therefore, this work can be called an auxiliary biographical study.

We will also dwell in detail on the question of fashion itself, namely, what is the fashion that is seen by leading designers, what is the development of fashion, and why fashion largely determines the lifestyle and behavior of civilization. clothes.

Keywords: fashion; couturier; self-improvement; career; education of the designer; modeling; production of

3

агальна постановка проблеми. Кожна молода людина, що вибирає напрям діяльності свого майбутнього життя, мотивується, безумовно, безліччю чинників, серед яких власні схильності, що проявляються 3 дитинства, поради батьків і найближчого 
оточення, успіхи однолітків і просто модні тенденції суспільства. Однією з найбільш значних причин вибору професії дизайнера одягу є приклад карколомної кар'єри людей, зайнятих у мейнстрімі актуальних світових напрямів моди.

Що мотивує студента, який вибирає професію кутюр'є? Яких вершин можна досягти на цьому терені? Йому подобаються гламур і блиск столичної богеми або жадання уваги на подіумі в променях слави або його притягує мовчазне загальне визнання, або він відчуває у собі бездонний колодязь ідей і спрагу поділиться ними зі світом, а може, це звичайне бажання побудувати прибуткову справу і пошиття одягу є лише засобом, нічим не кращим і не гіршим за інших? Найбільш ймовірніше за все це цілий мотиваційний комплекс почуттів і бажань кожного початківця, розплутати який буде складно навіть для професійного психоаналітика, але ми і не ставимо таких завдань.

Аналіз останніх досліджень та публікацій. Відповідно до сучасних загальноприйнятих уявлень, мода як явище мультидисциплінарне, [5] все ж, є предметом вивчення, здебільшого, гуманітарних, соціально-психологічних наук. Щоб вловити тенденції моди в іiі динамічному аспекті, необхідно не тільки ретельно вивчати безліч універсальних наук про людину: антропологію, соціологію, психологію, але ще й враховувати різноманіття місцевих культур і традицій суспільства в даному конкретному ареалі. Також становить інтерес вивчення моди в рамках економічної теорії, яка багато в чому визначає споживчі настрої, перспективні напрями швейної індустрії, підвищення прибутковості виробництва залежно від правильного вибору реалізованої продукції.

Відповідно до загальноприйнятих норм, структура моди включає:

1. Модні стандарти як модель поведінки.

2. Модні об’єкти (аксесуари, одяг, ідеї) як основні засоби матеріального вираження.

3. Модні цінності, коли ті чи ті об'єкти набувають статусу модного значення, тобто приймають якісну трансформацію стаючи модними, або навпаки, виходячи з моди [11].

Однак мода багато в чому має суб'єктивний характер. Навіть незважаючи на прискорення інтеграційних процесів сучасне цивілізоване суспільство ділиться на різні соціальні групи за багатьма критеріями, основним 3 яких, мабуть, можна виділити віковий.

Для молоді мода є найважливішою сферою життя: “У моді молодь знаходить можливість задовольнити цілий ряд гострих потреб, головною
3 яких $є$ потреба в самоствердженні, самовираженні і відчутті своєї значимості, потім потреби в спілкуванні і грі, в зміні вражень та естетичній насолоді" [9].

Молодь визнає як плюси, так і мінуси модної індустрії і активно користується іiі продуктами [12]. Саме молодь є ключовою креативною ланкою у прийнятті, створенні і розвитку нових модних концепцій та ідей. Тому важливість підготовки і гідної освіти в сфері високої моди серед молоді автор статті вважає обов'язковим пріоритетом для успішного розвитку подальшої модної індустрії в Україні.

Формування мети статті. Огляд успішного кар'єрного шляху провідних дизайнерів світу 3 метою надання студентам факультету дизайну гідного наслідування прикладу, та мотивувати молодь на можливість досягнення найвищої мети, завдяки наполегливій праці та цілеспрямованому самовдосконаленню.

Виклад основного матеріалу. Отже, що ж таке славнозвісна мода? Звернемося до класичних визначень: “Мода - це сукупність звичок, цінностей і смаків, прийнятих в певному середовищі в певний час. Мода може визначати тип або форму одягу і аксесуарів, набір ідей, принципи поведінки людей в суспільстві”, і тут же, "Важливим атрибутом моди є дотримання новому і представлення нового як цінності. Модний одяг, має схожість з прикладами, узятими у минулому" [10]. Сучасна мода одягу пов'язана з принципом сезону. Визначають всього два основні напрями: весна-літо і осінь-зима.

Якщо ми говоримо про будинок “високої моди" в його сьогоднішньому розумінні, це передбачає наявність необхідних атрибутів. Існує декілька необхідних умов, що пред'являються французьким Синдикатом високої моди (haute couture) - “потрібно мати основне виробництво i бутики в Парижі, щоб вони юридично входити у відомство французького Департаменту промисловості. Кількість службовців в Будинку Моди має бути не менше 15. До осінньо-зимового і весняно-літнього сезону двічі на рік мають бути створені колекції: для кожного дефіле по 35 денних і стільки ж вечірніх моделей. При виготовленні нарядів обов'язкове застосування ручної праці. Кількість машинних швів не повинна перевищувати 30 \%”.

Кожен будинок моди має унікальний стиль i дотримується його. Еволюціонують методи пошиття, з'являються нові тканини, прогресують усі супутні виготовленню одягу механізми, але унікальний стиль будинку моди залишається і підкреслюється. 
Приміром, девіз будинку мод Шанель "Простота $\epsilon$ лейтмотивом істинної елегантності". Шанель асоціюється 3 елегантністю, жіночністю і витонченістю.

Не кожного перспективного дизайнера візьмуть на роботу в той чи той інший будинок моди. Як правило, відбирають не лише яскравих і креативних молодих художників, але і тих, чия творчість перекликається зі стилістикою конкретного Будинку Моди. Навряд, чи епатажних, хоч і видатних майстрів, навіть зі світовим ім'ям, запросять у Будинок Мод, що вибрав лейтмотивом діяльності підкреслену стриманість фасону.

Нижче ми представляємо список провідних дизайнерів одягу, життєвий шлях яких плануємо розглядати, і що представляють або представляли раніше основні паризькі Будинки Мод :

1. Джон Гальяно - провідний дизайнер Christian Dior протягом 15 років, зробив справжню революцію в haute couture, створюючи моделі дивовижні за новизною і змістом, які надихають усіх цінителів моди останні 20 років. Епатажний стиль Джона Гальяно нікого не може залишити байдужим [1]. Закінчивши в 1985 р. коледж мистецтва і дизайну святого Мартіна в Лондоні показом декількох колекцій, що мали певний успіх, переїжджає до Парижа (1988), де знайомиться 3 редактором журналу "Vogue" Ганною Винтур. Нове знайомство допомагає молодому художникові стати на ноги і організувати декілька показів нових колекцій у невеликому приватному особняку, не призначеному для дефіле, який не мав достатньої місткості для усієї охочої публіки і критиків. Проте свіжий погляд молодого кутюрье звертає на себе увагу і пропозиції від передових feshion - студій до провідних будинків летять одне за одним, і в 1995 р. Гальяно очолює будинок "Givenchy”, з якого переходить в консервативний будинок "Dior”, вдихнувши новий молодіжний зміст і надаючи будинку нові відтінки яскравого, експресивного стилю.

Багато сучасників відзначали надзвичайну енергійність, життєрадісність і працездатність молодого Гальяно, здатного кожен місяць створювати не лише повноцінну колекцію, а це не менше 35 моделей, але і просувати в майбутнє само розуміння моди, бути першовідкривачем фантастичної пишності розкішного гламуру в жіночому одязі кінця ХХ ст.

Проте придивимося уважніше до самого коледжу мистецтва і дизайну святого Мартіна. Диплом і знання, отримані Гальяно в цьому закладі, стали пропуском до дебюту кар'єрної реалізації і становлення художньої майстерності.
За спогадом самого Джона, працювати доводилося по 15 годин на день, включаючи неділю [2]. Неймовірне навантаження і вимоги креативу, коли студентам напередодні складання іспитів доводилося малювати по 200 моделей і самим шити зразки. На другому курсі навчання для учнів коледжу починається практика, i 3'являється шанс стажуватися у будь-якому великому модному бренді. Але і тут практикантів чекає виснажливе випробування на витривалість, оскільки доводиться щоденно працювати по 12 14 годин, а в завершальних тижнях, напередодні показу, вимагається бути присутнім на примірках всю ніч, аж до 6 ранку.

Оглядаючи курс коледжу святого Мартіна, можна констатувати, що за блиском і шиком моди стоїть важка, стомлива праця, часто нудна, але без якої неможливо уявити собі справжній світ високої моди.

2. Жан Поль Готьс - модельєр, засновник і президент французького будинку моди 3 однойменною маркою Jean Paul Gaultier S.A. 3 ім'ям Готье що зв'язують піднесення високої моди середини 80-х рр. На відміну від більшості дизайнерів, Жан Поль не отримав спеціальної освіти модельєра, але пристрасть до одягу проявилася вже 3 дитинства - улюбленому іграшковому ведмедеві Жану був пошитий костюм космонавта і навіть вінчальна сукня. До 18 років молодий художник зібрав пристойне портфоліо ескізів жіночої сукні, яке й представив П'єру Кардену. Роботи дуже сподобалися маститому кутюр'є, і Готье був запрошений на роботу у будинок Pierre Cardin на посаду асистента [3].

Через 6 років, (1976) вже досвідчений майстер створює власну марку. Творчості Готье властиве змішання стилів і матеріалів, дослідження нових напрямів у моді, що беруть початок глибоко у бунтівній душі дизайнера в спробах наблизити розуміння жіночої краси і набути гармонії там, куди більшість сучасників не наважуються заглянути.

Знайти єдність нового образу і не сфальшувати, викликати схвалення критиків і захоплення пань, що уявляють демонстрацію нових суконь у вечірніх салонах, - ось безперечний доказ професіоналізму справжнього знавця своєї справи.

Авторству Готьє належить знаменитий ліф conebra, який, за визначенням самого автора, був придуманий ще в дитячі роки для плюшевого ведмедя, але отримав визнання лише після світового турне Мадонни.

Для гардероба фантастичного фільму “П’ятий елемент” Готьє намалював більше 1000 моделей 
і багато хто з них увійшов до кадру, наприклад, костюми стюардес і хутряний наряд Рубі Рода. [4].

Дизайнер був одним із перших західних художників, хто надів на чоловіків спідниці. У 1984 р. він зробив колекцію спідниць для чоловіків, на основі шотландських картатих кілтів, які пропонував носити $з$ футболками, звичайними сорочками і чоловічими аксесуарами, чим випередив час і прибрав межу між чоловічими i жіночими одноосібними безперечними атрибутами. Усього через десять років цей напрям моди став цілком трендовим, і Олександр Маккуін (як і Гальяно, випускник коледжу мистецтва та дизайну святого Мартіна), і Еді Сліман створили плісировані спідниці для чоловіків.

Підсумовуючи вищесказане, можна 3 упевненістю стверджувати, що Жан Поль Готьє - це абсолютно геніальний, експресивний бунтар, цілком відданий роботі майстер своєї справи, що розсуває рамки загальноприйнятих уявлень не лише в моді, але і в деяких етичних питаннях, що, безумовно, тісно взаємопов'язано.

3. Карл Лагерфельд - легендарний німецький модельєр, що присвятив усе своє довге життя моді і ще за життя заслужив титул “короля моди” та “кайзера моди”. Упродовж тридцяти шести років він як художній керівник очолив знаменитий будинок Chanel [6].

Навчання, власне, виготовленню одягу, формування смаку і видатного стилю юного Лагерфельда почалося у Парижі в школі Синдикату високої моди (1953), куди він переїхав з Гамбурга у пошуках кар'єри. Примітно, що тоді там навчався і майбутній блискучий модельер і засновник будинку високої моди Ів Сен Лоран, 3 яким Лагерфельд подружився.

Не закінчивши навчання і не отримавши диплом дизайнера, Лагерфельд, проте, виграє престижний конкурс, організований міжнародним секретаріатом хутра, продемонстрував ескіз пальто, і отримав запрошення у будинок мод “П’єр Бальмен”, де працює впродовж чотирьох років. Далі творчий шлях Лагерфельда набуває дискретного характеру, оскільки дизайнер займається, фактично, фрілансовою діяльністю, міняє безліч компаній і створює масу нових колекцій для італійських і французьких будинків, серед яких Chloe, Krizia, Charles Laurdan i Fendi.

Свідченням визнання роботи художника $\epsilon$ запрошення в 1974 р., на посаду професора до Віденської вищої школи прикладного мистецтва.

Але все ж основоположною віхою у творчості Карла Лагерфельда, $є$ запрошення зайняти місце художнього керівника лінії прет-а-порте у будинку
Chanel. Витончений, вкрадливий стиль дизайнера знайшов співзвуччя з компанією, спочатку задуманою неперевершеною Коко Шанель, як зразок елегантної простоти силуету і блискучого стилю класичних форм. Віддаючи належне унікальному духу Шанель, дизайнер привніс нове, сучасне бачення моди до будинку і притягнув нову клієнтуру, розширюючи діапазон доброго смаку серед представників різних вікових і культурних груп.

4. Крістіан Лакруа - народився в сім’ї інженерів у травні 1951 р., в невеликому південному, провінційному містечку Арль на живописному узбережжі Середземного моря, східніше Монпельє [7]. Ще дитиною, він проводив вільний від навчання час за розглядуванням модних журналів і відвідуванням музею історичного костюма, який був поблизу від будинку. Таким чином сформувалася пристрасть майбутнього дизайнера до сценічного костюма, яка допомогла розвинути унікальні риси модного стилю Лакруа, з явною тягою до історичної французької сукні XVIII -XIX ст.

Коли зайшла мова про вищу освіту - вибір виявився однозначний, і в 1973 р. Лакруа закінчує університет Монпельє за фахом історія мистецтв, захистивши дипломну роботу на тему "Історичний костюм в живописі 18-го ст".

Жадоба до знань спрямовує юного випускника до продовження навчання в Сорбоні на факультеті історії мистецтв. Подібно до славнозвісного Вольтерівського садівника, що ростить свій сад, Лакруа знаходить навіть більше філософськи благословенне призначення для себе - працювати доглядачем в Луврі, насолоджуючись увічненою красою людського генія.

Але доля розпорядилася інакше і приготувала для Крістіана яскраву долю блискучого маестро моди, коли звела його з майбутньою дружиною Франсуазою. Саме завдяки іiі турботам Лакруа влаштовується (1981) у Будинок Моди Жана Пату, що принесло компанії значний успіх та потроїло обсяг продажів. Накопивши достатній досвід у веденні справ, 1987 року модельєр створює власний будинок мод.

Характерною особливістю стилю Крістіана Лакруа є вільний крій сукні, широкі, просторі форми і багатошаровість, що містить велику кількість аксесуарів, прикрас і вишивки. Наряди дизайнера повні декоративних елементів, коштовностей, воланів, жабо і комірів “раф”. Доповнюються образи колекцій надлишком головних уборів, різноманітних капелюхів, беретів, накидок, шарфів і ін., загалом усім тим, що можна зустріти в історичному костюмі XVIII -XIX ст. [8]. 
Багато критиків акцентували свою увагу на театральності костюмів, виготовлених дизайнером, що стало наслідком зміни поглядів на моду цілого покоління 90-х рр.

Проте успіх творчого пошуку не завжди супроводжується прибутковістю, і в 2009 р. дизайнер був вимушений продати марку, залишивши за собою пост художнього директора.

Нині Крістіан Лакруа покинув світ високої моди, в основному займається, тим, до чого завжди більше лежала душа 3 малих років - сценічними костюмами для балету та опери. Неймовірний фонтан креативу знайшов нове втілення, радуючи прихильників творчості художника і надихаючи молодь.

5. Емануель Унгаро - французький дизайнер італійського походження, народився в південній Італії на березі Адріатики в 1933 р. Сім’я втекла 3 рідної країни, рятуючись від фашистського режиму Муссоліні, і почала усе 3 нуля в південному французькому містечку Прованс [13]. Батьки Унгаро були кравцями і вимушені були багато працювати, щоб прогодувати семеро дітей. 3 малих років Эмануэль допомагав родині заробляти на життя, практикуючись на маминій швацькій машинці і асистуючи батькові в крамниці. Необхідно додати, що в дитинстві хлопчикові довелося пережити Другу світову війну, з усіма знегодами і поневіряннями. Незважаючи на це, дитина росла життєрадісною, повною віри у своє призначення - займатися пошиттям одягу. У 22 роки молодий Унгаро покидає улюблений Прованс і з легким серцем їде в Париж підкорювати світовий Олімп високої моди, де влаштовується спочатку в звичайне ательє Maison Camps tailors, працюючи простим закрійником, а пізніше - стилістом.

Фортуна була прихильна до Унгаро і його беруть на роботу у Будинок Мод Кристобаля Баленсіага. Молодий вихованець відомого кутюрьє швидко схоплює тонкощі прийомів крою, драпіровки, ескізів і усього, що складає гармонію дизайну одягу, і за шість років, у 1956 р., стає повноправним дизайнером, якому доручають управління Мадридським відділенням будинку Баленсіага [14].

Багатьох задовольнив би досягнутий успіх, але не таким був Эмануэль Унгаро. У 1965 р. разом зі своїм товаришем Андре Курежем він відкриває власний Будинок Мод з фірмовою буквою “U” на вивісці, починаючи особисте ризиковане підприємство. Сумніви недовго тривожили засновників - оглушливий успіх, що супроводжував перші кроки фірми не був випадковим, він виявився твором наполегливої підготовчої праці і удачі. Апогею популярності будинок Унгаро досяг у 70-х рр. минулого століття. Стиль Унгаро - строкатість колірної палітри, епатажність, бажання виділитися, чуттєвість, але все ж таки головною рисою була зручність. "Сукню не треба носити, в ній треба жити” - ось просте, практичне і геніальне становлення дизайнера до моди і до своєї творчості загалом.

Висновок. Ми простежили життєвий i кар'єрний шлях деяких видатних кутюрьє зі світовим ім'ям і постаралися знайти єднальні нитки, що об'єднують їх тріумфальне просування і вказують нам шлях до успіху на терені високої моди.

По-перше - це вибір майбутньої професії, здійснений з абсолютною визначеністю і без усяких сумнівів, вибір, продиктований не лише життєвими обставинами або порадами близьких людей, але й покликом серця, служіння справі що приносить душевну радість і красу в цей світ. Причому цей вибір, зроблений дизайнерами ще в глибокому дитинстві пройшов для них практично непоміченим, неначе стихія моди сама вибрала своїх провідників собі в служіння.

По-друге - освіта, набуття навичок роботи 3 матеріалом, що вимагає багатьох і багатьох годин практики, вивчення історичного костюма, ознайомлення з новинками, наслідування моди 3 тим, щоб дизайнер ясно уявляв собі прийдешні тенденції, передбачав і нарешті очолював їх, відкриваючи нові горизонти моди та fashion індустрії загалом.

По-третє - це дивна працездатність, яка абсолютно не обтяжувала художників, але навпаки, додавала енергії і надихала на створення майбутніх колекцій.

I нарешті по-четверте, на наш погляд, найважливіша риса - це цілковита відданість своїй справі, знання і віра, які заряджали ентузіазмом оточення. Ця переконаність у правильності вибору, свого призначення, свого таланту - незамінний атрибут лідера, діючий як на найближче оточення майстра - співробітників, співзасновників, інвесторів, так і на віддалених, простих шанувальників таланту дизайнера, звичайних людей, притягнених у вихор моди і закручених у вир гламуру, блиску і святкової ейфорії своєю чарівливою магією в центрі світової культури, в центрі Парижа.

\section{ЛІТЕРАТУРА}

1. Джон Гальяно. URL: https://ru.wikipedia.org/wiki/ Гальяно, Джон (дата звернення: 10.04.2021)

2. Джон Гальяно. URL: https://fancy-journal.com/ 
celebrities/vsjo-o-znamenitostyakh/4061-dzhon-galyanobiografiya (дата звернення: 21.04.2021)

3. Жан-Поль Готье. URL: https://ru.wikipedia.org/wiki/ Готье,_Жан-Поль (дата звернення: 10.04.2021)

4. Жан-Поль Готье. URL: https://www.vogue.ru/ fashion /news/1_enfant_terrible_zhan_polyu _gote_66_let (дата звернення: 21.04.2021)

5. Жилина А.А., Моор С.М. Современные исследования социальных проблем. Науковий журнал. Modern Research of Social Problems, №6 (50), 2015. URL: https://cyberleninka.ru/article/n/sovremennoe-ponimaniesuschnosti-mody (дата звернення 24.06.2021)

6. Карл Лагерфельд. URL: https://ru.wikipedia.org/ wiki/Лагерфельд, Карл (дата звернення: 10.04.2021)

7. Кристиан Лакруа. URL: https://ru.wikipedia.org/ wiki/Лакруа, Кристиан (дата звернення: 22.04.2021)

8. Кристиан Лакруа, биография. URL: https:// 24smi.org/celebrity/24069-kristian-lakrua.html (дата звернення: 22.04.2021)

9. Масленцева Н.Ю. Молодежная мода в одежде в условиях современной России: социологический анализ. Екатеринбург. 2004. URL: https:// www.dissercat.com/content/molodezhnaya-moda-vodezhde-v-usloviyakh-sovremennoi-rossiisotsiologicheskii-analiz (дата звернення: 24.06.2021)

10. Мода. URL: https://ru.wikipedia.org/wiki/Мода (дата звернення: 10.04.2021)

11. Поплевина В.А. Научные исследования моды как социально-культурного явления. Социальноэкономические явления и процессы. Научный журнал. URL: http://journals. tsutmb.ru/a8/ upload/ auto/59/41/ temp.5941767a1 abefef615ec0ea47be 1894d.pdf (дата звернення 24.06.2021)

12. Репецкая А.И. Отношение молодежи к феномену моды в одежде: региональный аспект. Научный журнал. Известия Уральского федерального университета. Екатеринбург, 2019. №14/1(185), С.7885. URL: https://elibrary.ru/item.asp?id=37335962 (дата звернення 26.06.2021)

13. Эмануэль Унгаро. URL: https://esquire.ru/styleand-grooming/145594-plate-ne-nuzhno-nosit-v-nemnuzhno-zhit-chto-sdelal-dlya-mody-i-zhenshchin-velikiymodeler-emanuel-ungaro/ (дата звернення: 22.04.2021)

14. Эмануэль Унгаро, биография. URL: http:// wayoffashion.ru/dizainery/ emanuel-ungaro.html (дата звернення: 22.04.2021)

\section{REFERENCES}

1. John Galliano. Available at: https://en.wikipedia.org/ wiki/John_Galliano (accessed 23 Apr. 2021) [in Ukrainian].

2. John Galliano. Available at: https://fancyjournal.com/celebrities/vsjo-o-znamenitostyakh/4061dzhon-galyano-biografiya (accessed 21 Apr. 2021) [in Ukrainian].
3. Jean-Paul Gaultier. Available at: https:// en.wikipedia.org/wiki/Jean_Paul_Gaultier (accessed 23 Apr. 2021) [in Ukrainian].

4. Jean-Paul Gaultier. Available at: https:// www.vogue.ru/fashion / news / 1 enfant terrible zhan_polyu_gote_66_let (accessed 23 Apr.2021) [in Ukrainian].

5. Jilina, A.A., \& Moor, C.M. (2015). Sovremennye issledovaniya sotsialnykh problem [Contemporary research on social problems]. Science journal. No. 6(50). Available at: https://cyberleninka.ru/article/n/ sovremennoe-ponimanie-suschnosti-mody (accessed 24 June 2021) [in Russian].

6. Karl Lagerfeld. Available at: https://en.wikipedia.org/ wiki/Karl_Lagerfeld (accessed 21 Apr. 2021) [in Ukrainian].

7. Kristian Lakrua. Available at: https://en.wikipedia.org/ wiki/Christian_Lacroix (accessed 21 Apr. 2021) [in Russian].

8. Kristian Lakrua, biography. Available at: https:// 24smi.org/celebrity/24069-kristian-lakrua.html (accessed 21 Apr. 2021) [in Russian].

9. Maslentseva, N.Yu. (2004). Molodezhnaya moda v odezhde $\mathrm{v}$ usloviyakh sovremennoy Rossii: sotsiologicheskiy analiz [Youth fashion clothes in the conditions of modern Russia: a sociological analysis]. Ekaterinburg. Available at: https://www.dissercat.com/ content/molodezhnaya-moda-v-odezhde-v-usloviyakhsovremennoi-rossii-sotsiologicheskii-analiz (accessed 24 June. 2021) [in Russian].

10. Moda [Fashion]. Available at: https:// en.wikipedia.org/wiki/Fashion (accessed 23 Apr.2021) [in Ukrainian].

11. Poplevina, V.A. Nauchnye issledovaniya mody kak sotsialno-kulturnogo yavleniya. Sotsialnoekonomicheskie yavleniya i protsessy [Scientific research of fashion as a socio-cultural phenomenon. Socioeconomic phenomena and processes]. Scientific journal. Available at: http://journals.tsutmb.ru/a8/upload/auto/59/ 41/temp.5941767a1 abefef615ec0ea47be 1894d.pdf (accessed 24 June 2021) [in Russian].

12. Repeckaya, A.I. (2019). Otnoshenie molodezhi k fenomenu mody v odezhde: regionalnyy aspekt [The attitude of young people to the phenomenon of fashion in clothes: a regional aspect]. Science journal. Bulletin of the Ural Federal University. Ekaterinburg, no.14/1(185), pp.78-85. Available at: https://elibrary.ru/ item.asp?id=37335962 (accessed 26 June 2021) [in Russian].

13. Emanuel Ungaro. Available at: https://esquire.ru/ style-and-grooming/145594-plate-ne-nuzhno-nosit-v-nemnuzhno-zhit-chto-sdelal-dlya-mody-i-zhenshchin-velikiymodeler- emanuel-ungaro (accessed 21 Apr. 2021) [in Russian].

14. Emanuel Ungaro, biografiya [Emanuel Ungaro, biography]. Available at: http://wayoffashion.ru/dizainery/ emanuel-ungaro.html (accessed 21 Apr. 2021) [in Russian].

Стаття надійшла до редакції 10.05.2021

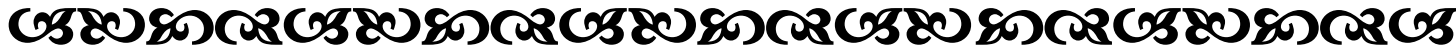

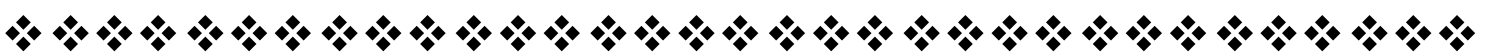

